\title{
Relationship between nucleic acid ratios and growth in Listeria monocytogenes
}

\author{
Michael G. Milner, † Jon R. Saunders and Alan J. McCarthy
}

School of Biological Sciences, University of Liverpool, Liverpool L69 7ZB, UK
Author for correspondence: Alan J. McCarthy. Tel: +44 151794 4413. Fax: +44 1517944401. e-mail: AJ55M@liverpool.ac.uk

\begin{abstract}
Listeria monocytogenes is a pathogen whose distribution in a range of foodstuffs requires the development of methods for sensitive and rapid detection. Molecular biological methods usually rely on specific detection of $L$. monocytogenes rDNA directly amplified by the application of PCR to DNA extracts. Information on the metabolic status of $L$. monocytogenes populations would be valuable and can, in theory, be provided by quantitative detection of rRNA itself. Both fluorometry and oligonucleotide probe assays were applied to $L$. monocytogenes cultures to quantify RNA and DNA and produced more meaningful data than previous estimates for bacteria based on eukaryotic nucleic acid standards. In batch culture, the RNA-DNA ratio was found to be greatest at the end of exponential growth, after which RNA became degraded in accordance with the rapid decrease in viability. When the pH of the medium was controlled at neutrality, culture viability was dramatically extended and although RNA was degraded, intact DNA was maintained for the duration of the experiment. Ribosome numbers per cell were estimated to decrease from about 25000 observed during mid-exponential growth to about 600 during stationary phase, under pH-controlled conditions. Like Escherichia coli, therefore, $L$. monocytogenes loses viability and rRNA rapidly once exponential growth has ceased in batch culture. However, much improved survival of a culturable $L$. monocytogenes population when $\mathrm{pH}$ is controlled has clear implications for the persistence of this species in buffered environments such as dairy products.
\end{abstract}

Keywords : rRNA, fluorometry, RNA-DNA ratio

\section{INTRODUCTION}

Listeria monocytogenes is an important foodborne pathogen responsible for systemic infections (listeriosis) that predominantly occur in neonates, geriatric and immunocompromised patients (Farber \& Peterkin, 1991). The organism is widely distributed, particularly in unpasteurized dairy foods and cooked meat products (Farber \& Peterkin, 1991; Ferron \& Michard, 1993; Gilbert et al., 1989; Pine et al., 1989; Verheul et al., 1995; Young \& Fogeding, 1993). Consequently, detection, enumeration and viability assessment of $L$. monocytogenes is of importance to both the food industry and clinicians alike (Gilbert, 1989; Hof \& Rocourt, 1992; Nørrung \& Skovgaard, 1993).

\footnotetext{
† Present address: Clean Environment Management Centre, University of Teesside, Middlesborough TS1 3BA, UK.
}

Conventional methods for detection of L. monocytogenes use enrichment and selective isolation followed by biochemical tests (Farber \& Perkin, 1991; McLauchlin \& Pini, 1989). Such procedures are valuable, but speed and sensitivity can be improved by the use of PCR-based methods (Bessesen et al., 1990; Cooray et al., 1994; Scheu et al., 1999). However, detection of DNA does not discriminate between viable and non-viable cells and DNA can be associated with detrital material (Dell'Anno et al., 1998). In theory, RNA detection is indicative of metabolically active organisms, but often requires an enrichment step prior to the molecular biological analysis (Blais et al., 1997; Klein \& Juneja, 1997). This precludes simple, rapid quantification and suffers from poor sensitivity when attempted directly on food samples (Powell et al., 1994; Wang et al., 1992; Cano et al., 1995; Makino et al., 1995).

It has been established that bacterial growth rate and 
cellular RNA concentration are positively correlated in a number of bacterial species (Kjellgaard \& Kurland 1963; Rosset et al., 1966; Gausing, 1977; Kerkhof \& Ward, 1993; Amann et al., 1990a, b; Muttray \& Mohn, 1998). Increased levels of rRNA associated with increased growth rates (Bremer \& Dennis, 1987) would effectively increase L. monocytogenes detection sensitivity if rRNA targeted probes were used. However, the correlation is not absolute for the growth of all bacterial species and the relationship is poor at low growth rates (Kramer \& Singleton, 1992; Kerkhof \& Ward, 1993; Kerkhof \& Kemp, 1999). Under such conditions the cellular rRNA concentration approached the detection limits of the techniques used.

Definition of the relationship between L. monocytogenes growth and cellular RNA content is required prior to the development of meaningful RNA-based detection methods. In this paper, we use fluorometry and quantitative nucleic acid probing to determine RNA-DNA ratios for L. monocytogenes in relation to the batch culture growth cycle, and culture viability in the presence and absence of $\mathrm{pH}$ control.

\section{METHODS}

Nucleic acid extraction. All solutions were prepared following standard procedures for the prevention of RNase activity (Blumberg, 1987). Nucleic acids were extracted from cells by an enzymic digestion method. Briefly, biomass was harvested by centrifugation for $10 \mathrm{~min}$ at $740 \mathrm{~g}$, cell pellets were resuspended in $70 \%(\mathrm{v} / \mathrm{v})$ ethanol and stored at $4{ }^{\circ} \mathrm{C}$ until required. Cell pellets were resuspended in $200 \mu \mathrm{l}$ lysis buffer (50 mM Tris/HCl, pH 8.0, $1 \mathrm{mM} \mathrm{CaCl}_{2}, 1 \%, \mathrm{w} / \mathrm{v}, \mathrm{SDS}$ ) to which Proteinase K (Roche Diagnostics) was added to a final concentration of $500 \mu \mathrm{g} \mathrm{ml}^{-1}$. Samples were incubated in Eppendorf tubes at $55^{\circ} \mathrm{C}$ for $60 \mathrm{~min}$ and then to each was added $1 \mathrm{ml}$ phenol/chloroform/isoamyl alcohol (25:24:1; Sigma Aldrich). Tubes were mixed by inversion and centrifuged at $9440 \mathrm{~g}$ for $5 \mathrm{~min}$ at room temperature. The aqueous phase was retained and to each was added $1 \mathrm{ml}$ absolute ethanol. Nucleic acids were precipitated at $-20{ }^{\circ} \mathrm{C}$ for at least $1 \mathrm{~h}$ before centrifugation at $9440 \mathrm{~g}$ for $30 \mathrm{~min}$ at $4{ }^{\circ} \mathrm{C}$. Pellets were resuspended in $200 \mu \mathrm{l}$ TE buffer $(10 \mathrm{mM}$ Tris $/ \mathrm{HCl}$, $\mathrm{pH} 8 \cdot 0,1 \mathrm{mM}$ EDTA) and stored at $-70^{\circ} \mathrm{C}$ before examination and subsequent quantification by either fluorometry or oligonucleotide hybridization.

Agarose gels $(0 \cdot 8-1 \cdot 2 \%, \mathrm{w} / \mathrm{v})$ were prepared in $1 \times \mathrm{TAE}$ buffer $(2 \mathrm{ml} 50 \times$ TAE; $0.5 \mathrm{M}$ Tris $/ \mathrm{HCl}, \mathrm{pH} 7 \cdot 6 ; 0.05 \mathrm{M}$ EDTA; $57 \cdot 1 \mathrm{ml}$ glacial acetic acid) and $2 \mu \mathrm{l}$ ethidium bromide $\left(10 \mathrm{mg} \mathrm{ml}^{-1}\right)$ was added to $100 \mathrm{ml}$ molten agarose prior to pouring the gel. Gel equipment was suitably treated to inactivate RNases and used exclusively for RNA work. Nucleic acid samples $(1-15 \mu \mathrm{l})$ were mixed with $4 \mu \mathrm{l}$ loading buffer $(50 \%, \mathrm{v} / \mathrm{v}$, glycerol, $50 \%$, v/v, TE buffer, $0.05 \%$, w/v, bromophenol blue) prior to loading onto the gel. Nucleic acids were separated by electrophoresis at $90 \mathrm{~V} \mathrm{~cm}^{-1}$ for $1 \mathrm{~h}$ and visualized on a UV transilluminator.

Fluorometric quantification of nucleic acid extracts. Standard curves for fluorometric determination of DNA or RNA concentration were prepared using serial dilutions of chromosomal DNA from L. monocytogenes ATCC 19111 (undiluted concentration $5.68 \mu \mathrm{g} \mathrm{ml}^{-1}$ determined by $A_{260}$ ) and E. coli $16 \mathrm{~S}$ and $23 \mathrm{~S}$ rRNA mixture (Roche Diagnostics 206938, $4 \mu \mathrm{g} \mathrm{ml}^{-1}$ ) in molecular grade water. Fluorescence of nucleic acid samples was recorded on a Perkin Elmer 3000 Spectrofluorometer. Samples $(10 \mu \mathrm{l})$ were added to fluorometry cuvettes and to each was added $3 \mu \mathrm{l}$ staining solution (10 mg ethidium bromide $\mathrm{ml}^{-1}$ in $5 \mathrm{mM}$ Tris $/ \mathrm{HCl}, \mathrm{pH} 8 \cdot 0,10 \mathrm{mM}$ EDTA) prior to addition of PBS to a final volume of $3 \mathrm{ml}$. Samples were mixed and equilibrated at $37^{\circ} \mathrm{C}$ for $15 \mathrm{~min}$ and fluorescence measured (excitation $\lambda_{260}$, emission $\lambda_{590}$; LePecq \& Paoletti, 1966) using slit widths of 10 and $20 \mathrm{~nm}$ for excitation and emission, respectively. No signal expansion was required throughout and all solutions were checked prior to use for quenching or enhancement of fluorescent signal. Unstained nucleic acids and PBS mixed with stain solution were used as negative controls. The data were subjected to linear regression analysis by a least squares method. Correlation coefficients were calculated by a Pearsons product moment coefficient (Sokal \& Rohlf, 1995).

L. monocytogenes nucleic acid extracts were digested with either DNase or RNase, as appropriate, before fluorescent quantification. To digest RNA, DNase-free RNase (Roche Diagnostics 1119915) was added $\left(3-15 \mathrm{U} \mathrm{\mu l}^{-1}\right)$. Nucleic acids were also incubated in the presence of $3 \mu \mathrm{l}$ RNase-free DNase (Roche Diagnostics 776785) after addition of DNase buffer (20 mM Tris/ $\mathrm{HCl}$ and $10 \mathrm{mM} \mathrm{MgCl}{ }_{2}, \mathrm{pH} 7 \cdot 4$ ) to each sample. All digestions were performed for $4 \mathrm{~h}$ at $37^{\circ} \mathrm{C}$. The efficacy of DNA or RNA selective digestion had been assessed previously (data not shown). Fluorescence was determined as described above.

Quantitative oligonucleotide probe hybridization. Nucleic acids were applied to positively charged nylon membranes (Positive; Appligene) with a Minifold II vacuum manifold (Schleicher and Schuell) which had a sample footprint size of $6 \mathrm{~mm}^{2}$. For RNA immobilization, the manifold was soaked overnight in $0.5 \%(\mathrm{v} / \mathrm{v})$ diethylpyrocarbonate (DEPC)-treated water to inhibit RNase activity. Samples of RNA (maximum volume $50 \mu \mathrm{l}$ ) were mixed with 3 vols of a solution that contained $70 \%(\mathrm{v} / \mathrm{v})$ deionized formamide, $24 \%(\mathrm{v} / \mathrm{v})$ of a $37 \%(\mathrm{v} / \mathrm{v})$ filtered formaldehyde solution and $6 \%(\mathrm{v} / \mathrm{v}) 20 \times$ SSC ( $3 \mathrm{M} \mathrm{NaCl}, 0.3 \mathrm{M}$ sodium citrate, dissolved in $800 \mathrm{ml}$ DEPC-treated water and adjusted to $\mathrm{pH} 7 \cdot 0$ before adjusting the volume up to $1 \mathrm{l}$ ). Samples were heated for $15 \mathrm{~min}$ at $68^{\circ} \mathrm{C}$, chilled on ice and 2 vols of ice cold $20 \times$ SSC added before storage on ice until required. RNA was applied to the manifold according to manufacturer's instructions and slots were rinsed twice with $200 \mu \mathrm{l} 20 \times$ SSC under vacuum.

DNA samples (maximum volume $50 \mu \mathrm{l}$ ) were heated to $95^{\circ} \mathrm{C}$, chilled on ice and 1 vol. ice cold $20 \times$ SSC added before storage on ice until required. Subsequent application of DNA to the membrane followed the procedure described above for RNA. Both DNA and RNA were fixed onto the nylon membrane by air-drying for $1 \mathrm{~h}$ followed by cross-linkage at $80{ }^{\circ} \mathrm{C}$ for $1 \mathrm{~h}$. Membranes were wrapped in aluminium foil and stored at $4{ }^{\circ} \mathrm{C}$ prior to further treatment.

A probe, MV9RP2, was designed to be specific for $L$. monocytogenes rRNA (5'-ATAGTTTTATGGGATTAGCTC-3', position 1301-1281). This probe was designed by comparison of rDNA sequences deposited in the EMBL database (accession nos X56148-X56154; Collins et al., 1991). The CHECKрrobe package (Ribosomal Database Project, http://www.cme.msu.edu/RDP) was used to screen candidate sequences for diagnostic value and possible artefact formation. Experimental evaluation of this probe against rDNA obtained from a large collection of Listeria reference strains and clinical isolates showed cross-reactivity with a type strain of Listeria innocua ATCC 33090 (data not shown). 
Probes were end-labelled with $\left[\gamma^{32} \mathrm{P}\right] \mathrm{dATP}$ (ICN Supplies) and efficiency of labelling was determined using the procedure described by Hiorns et al. (1995). It was intended to use probe MV9RP2 to specifically detect L. monocytogenes DNA also, but preliminary experiments showed this to have poor sensitivity (data not shown). Consequently, oligonucleotide probe $\mathrm{pA}$, designed to be specific for all Eubacteria (5'-AGAGTTTGATCCTGGCTCAG-3'; position 8-28; Edwards et al., 1989), was used to detect L. monocytogenes rDNA. To monitor the relationship between L. monocytogenes rRNA and rDNA, subsequent experiments were performed using this organism in pure culture.

Membranes were prehybridized for at least $1 \mathrm{~h}$ in a buffer that comprised $5 \times \operatorname{SSPE}\left(0.78 \mathrm{M} \mathrm{NaCl}, 0.155 \mathrm{M} \mathrm{Na}_{2} \mathrm{HPO}_{4} . \mathrm{H}_{2} \mathrm{O}\right.$, $74 \mathrm{mM}$ EDTA, pH 7.4, made up to $800 \mathrm{ml}$ and adjusted to $\mathrm{pH} 7 \cdot 4$ prior to dilution to $1 \mathrm{l}), 20 \%(\mathrm{v} / \mathrm{v})$ deionized formamide, $0.02 \%$ SDS, $0.1 \%(\mathrm{w} / \mathrm{v}) \quad N$-lauryl sarcosine and blocking reagent $[2 \%, \mathrm{w} / \mathrm{v}$, of a solution that comprised $0 \cdot 1 \mathrm{M}$ maleic acid and $0.15 \mathrm{M} \mathrm{NaCl}$ adjusted to $\mathrm{pH} 8 \cdot 0$ prior to addition of blocking reagent $(10 \%, \mathrm{w} / \mathrm{v}$, Roche Diagnostics 1096176)]. Prehybridization solution was removed and membranes rinsed briefly in hybridization solution prior to addition of hybridization solution that contained $5 \times$ SSPE, $20 \%(\mathrm{v} / \mathrm{v})$ deionized formamide, $0.02 \%$ SDS, $0.1 \% \mathrm{~N}$-lauryl sarcosine and $10 \mathrm{pM}$ radiolabelled oligonucleotide probe. Membranes were hybridized overnight at $40^{\circ} \mathrm{C}$ prior to washing twice for $15 \mathrm{~min}$ at room temperature in the above solution. Filters were wrapped in cling film and X-ray film exposed by autoradiography for 2 and $7 \mathrm{~d}$ at $-70^{\circ} \mathrm{C}$. The autoradiograph signal was quantified with ImageQuant version 3.2 software running on a Molecular Dynamics Personal Densitometer. Signal (pixel) intensity above background was transferred to Microsoft Excel version 3.0 software where data manipulation was performed.

A preliminary experiment determined the response of oligonucleotide probe signal in relation to nucleic acid concentration. Briefly, titration series of either L. monocytogenes RNA or DNA were applied to nylon membranes and hybridized overnight in the presence of $10 \mathrm{pM}$ radioactively labelled oligonucleotide probe pA (DNA) or MV9RP2 (RNA) as outlined above. Autoradiographs were quantified and data analysed as described above.

Growth of $L$. monocytogenes in shake flask and $\mathrm{pH}-$ controlled batch culture. Conical flasks (5 l volume) containing 21 Tryptone Soya broth $\left(30 \mathrm{~g} \mathrm{l}^{-1}\right)$ supplemented with $0.3 \%(\mathrm{w} / \mathrm{v})$ yeast extract and $0.5 \%(\mathrm{w} / \mathrm{v})$ D-glucose (TSYGB) were inoculated with $2.5 \times 10^{10}$ c.f.u. of an overnight culture of L. monocytogenes ATCC 19111. Cultures were incubated at $37^{\circ} \mathrm{C}$ with shaking at 100 r.p.m. and samples $(10 \mathrm{ml})$ removed aseptically at intervals. Growth was determined by measurement of $\mathrm{OD}_{660}$ and viable counts determined on NAB plates (30 g Nutrient broth ${ }^{-1}$, pH 7.2; 12 g Agar No.2 Lab M l ${ }^{-1}$ ) supplemented with $0.5 \%(\mathrm{v} / \mathrm{v})$ defibrinated horse blood (Sigma Aldrich). In addition, $\mathrm{pH}$ was recorded by insertion of a $\mathrm{pH}$ probe into an aliquot of growth medium. Biomass was harvested by centrifugation of $1 \mathrm{ml}$ aliquots at $740 \mathrm{~g}$ for $5 \mathrm{~min}$. Nucleic acid extraction was performed prior to fluorescent and oligonucleotide assessment of RNA or DNA concentrations as described in detail above.

Fermenter vessels (LH Inceltech 501 series) that contained 1.5 1 TSYGB medium buffered with $\mathrm{KH}_{2} \mathrm{PO}_{4}\left(8 \cdot 5 \mathrm{~g} \mathrm{l}^{-1}\right)$ were prepared and maintained at $37^{\circ} \mathrm{C}, \mathrm{pH} 6.8$, for $24 \mathrm{~h}$ prior to inoculation with $10^{10}$ c.f.u. of an overnight culture of $L$. monocytogenes ATCC 19111. Constant rates of agitation, air flow and $\mathrm{pH}$ were maintained throughout. Samples were removed to determine $\mathrm{OD}_{660}$, viable counts and nucleic acid concentrations at intervals up to $456 \mathrm{~h}$, as described above.

\section{RESULTS AND DISCUSSION}

\section{Fluorometric quantification of nucleic acids}

Titration series of DNA from L. monocytogenes and a mixture of $16 \mathrm{~S}$ and $23 \mathrm{~S}$ rRNA from E. coli were prepared and stained with ethidium bromide and fluorescence recorded after equilibration. A linear relationship between nucleic acid concentration and fluorescence was obtained (Fig. 1). For DNA and RNA, linear regression analysis gave equations of form $y=m x+C: y=$ $119 \cdot 64 x+14 \cdot 81\left(r^{2}=0 \cdot 99\right)$ and $y=31 \cdot 05 x+7 \cdot 22\left(r^{2}=\right.$ $0.98)$, respectively. Hence, the ratio of the DNA/rRNA slopes was 3.85. Consequently, for determination of RNA-DNA ratios, all values of RNA fluorescence were multiplied by $3 \cdot 85$. A linear relationship between nucleic acid concentration and ethidium-bromide-mediated fluorescence has been observed (LePecq \& Paoletti, 1966), but calf thymus DNA and rat liver RNA were used and the slope ratio $(2 \cdot 82)$ was significantly different to that reported here. Kerkhof \& Ward (1993) calculated nucleic acid ratios for bacteria based on this conversion factor which may not be appropriate for bacterial nucleic acids. The nucleic acid ratios reported here are based on analysis of DNA from L. monocytogenes and rRNA from E. coli, which gave a significantly larger and presumably more reliable conversion factor for bacteria. Measurement of ethidium-bromide-mediated nucleic acid fluorescence will record amounts of all doublestranded nucleic acid. Consequently, fluorescent determination of RNA concentration will have included 5, 16 and 235 rRNA and tRNA, and may overestimate RNA-DNA ratio. However, this effect will probably be less pronounced at high growth rates as it has been reported previously that in rapidly growing E. coli cultures, $85 \%$ of RNA is rRNA (Bremer \& Dennis, 1987).

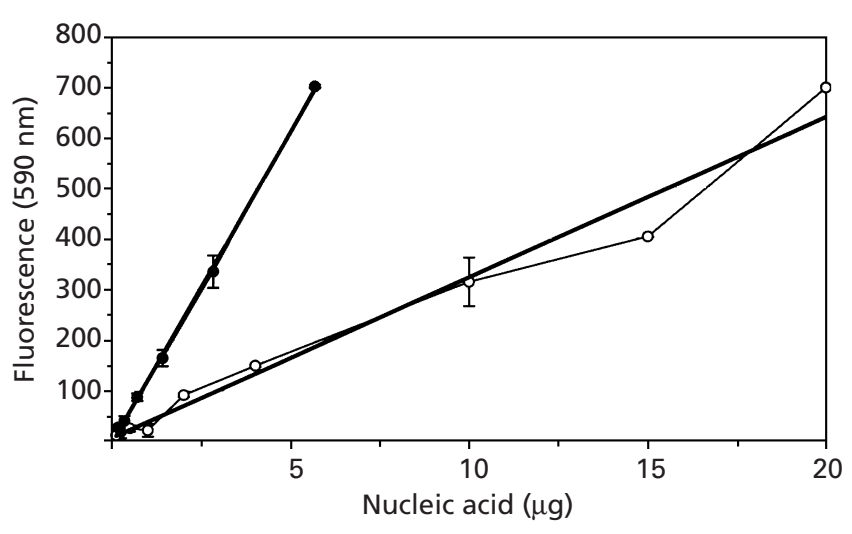

Fig. 1. Relationship between bacterial nucleic acid concentration and fluorescence. $\bullet$, L. monocytogenes DNA; O, E. coli rRNA. Fluorescence was determined by treatment with ethidium bromide as described in Methods. Data are means of triplicates \pm SD. Linear regression was determined as described in Methods. 
(a)

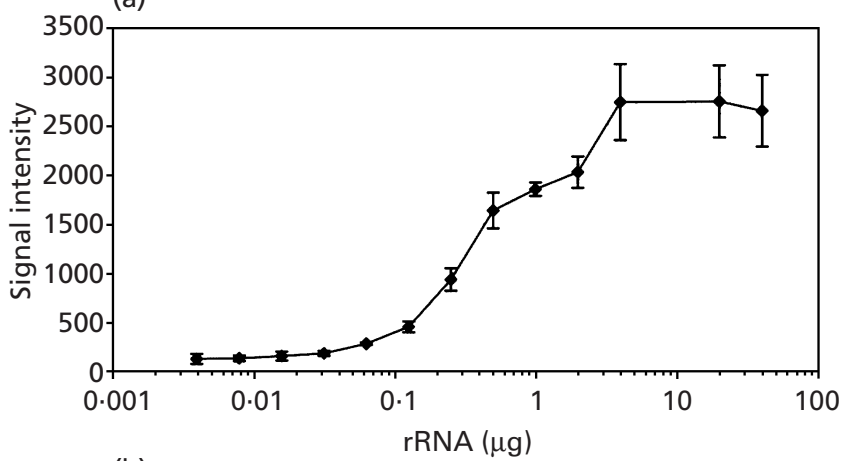

(b)

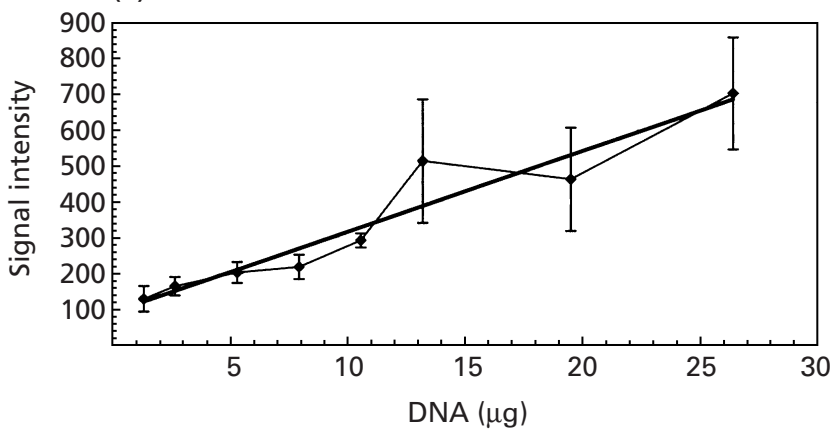

Fig. 2. Relationship between L. monocytogenes nucleic acid concentration and relative hybridization signal intensity. (a) rRNA hybridized to $L$. monocytogenes species-specific oligonucleotide probe MV9RP2. (b) DNA hybridized to eubacterial specific oligonucleotide probe pA $(y=22 \cdot 376 x+92 \cdot 644$, $\left.r^{2}=0.9135\right)$.

\section{Quantitative oligonucleotide probing}

In preliminary experiments, titration series of either $L$. monocytogenes RNA or DNA were immobilized onto nylon membranes and hybridized with radioactively labelled oligonucleotide probes. Subsequent examination of autoradiographs showed predictable relationships between nucleic acid concentration and signal intensity (pixel intensity above background).

Titration series of RNA showed a sigmoidal relationship between the logarithm of the nucleic acid concentration and pixel intensity (Fig. 2a). At the lowest amounts of nucleic acids applied ( $<740$ ng rRNA), the hybridization signal was below the detection threshold. This rRNA detection limit was equivalent to about 100 c.f.u. of a late-exponential-phase culture. Saturation of the nylon membrane occurred at $>5 \mu \mathrm{g}$ per slot. A linear relationship was observed between L. monocytogenes DNA concentration and pixel intensity for the range studied (Fig. 2b). Pixel intensities obtained for DNA were significantly lower than those obtained from RNA analysis (Fig. 2a) and the detection limit was about $1 \mu \mathrm{g}$ DNA. This is significantly higher than that determined by Kerkhof \& Ward (1993) and may be due to the many variables involved when preparing filters for oligonucleotide probing. However, the difference in amount of target sequence as a proportion of total nucleic acid applied is significant. This is estimated to be $0.4 \%$ of total RNA and $0.004 \%$ of total DNA (assuming lengths of $5 S+16 S+23 S$ rRNA to be $4566 \mathrm{bp}$ and an $L$. monocytogenes genome size of $3 \cdot 15 \times 10^{6} \mathrm{bp}$ ) (Michel \& Cossart, 1992). In subsequent experiments, titration series of nucleic acids of known concentration and experimental samples were immobilized onto nylon membranes simultaneously. Calibration curves for DNA and RNA were prepared for each experiment and used to determine the nucleic acid concentration from experimental samples. These values were used to determine the RNA-DNA ratio.

\section{Growth of L. monocytogenes in batch culture}

Growth of L. monocytogenes ATCC 19111 in the complex unbuffered medium showed predictable exponential, stationary and death phases as determined by $A_{660}$ (Fig. 3a). Viable counts determined on NAB plates, however, rapidly decreased to zero after $24 \mathrm{~h}$ incubation from a peak of $10^{10}$ c.f.u. $\mathrm{ml}^{-1}$ after $10 \mathrm{~h}$ incubation (data not shown). No further growth was observed over the remainder of the experiment $(168 \mathrm{~h})$. Culture $\mathrm{pH}$ decreased from 6.3 to 4.3 during the exponential growth phase of $13 \mathrm{~h}$ duration, probably due to production of lactic and acetic acids that reduced the $\mathrm{pH}$ to a level inhibitory to growth (Pine et al., 1989), a phenomenon that has been observed previously in L. monocytogenes (George \& Lund, 1992; ter Steeg \& Pieterman, 1991). Use of a Listeria selective recovery medium, for example modified Vogel-Johnson agar (Smith \& Buchanan, 1990), may have enabled the detection of viable cells beyond $24 \mathrm{~h}$.

Electrophoresis of nucleic acid extracts from this experiment gave clear bands of DNA and rRNA up until the $24 \mathrm{~h}$ sample in which nucleic acids had clearly undergone degradation (Fig. 3b). Both fluorometric and oligonucleotide probing analysis of nucleic acid extracts removed at intervals showed similar trends (Fig. 3c). RNA-DNA ratios were greatest at the end of the exponential growth phase (19 and $12.5 \mathrm{~h}$, as determined by oligonucleotide probing and fluorometry, respectively) and decreased rapidly thereafter. The RNA-DNA ratio decreased to about 2 after $72 \mathrm{~h}$ (Fig. 3c) and remained at that value thereafter (data not shown). Nucleic acid ratios may be expressed as ribosome numbers using the formula: ribosome number $=$ (RNA-DNA ratio $\times$ genome length)/the sum of the lengths of $5 \mathrm{~S}+16 \mathrm{~S}+23 \mathrm{~S}$ rRNA (Kerkhof \& Ward, 1993). After $12 \mathrm{~h}$ growth, ribosome numbers were calculated to be about 8600 per cell for an assumed genome length of $3 \cdot 15 \times 10^{6}$ bp and rRNA length of 4566 bp. At the end of the sampling period $(168 \mathrm{~h})$, the ribosome number per cell was calculated to be about 1400. However, these data should be regarded as tentative estimates. During exponential phase in batch culture the expected growth rate $(\mu)$ of the cell population will tend towards $\mu_{\max }$ and cell samples will be relatively homogeneous (Neidhardt et al., 1990). However, samples taken outside exponential phase will 
(a)

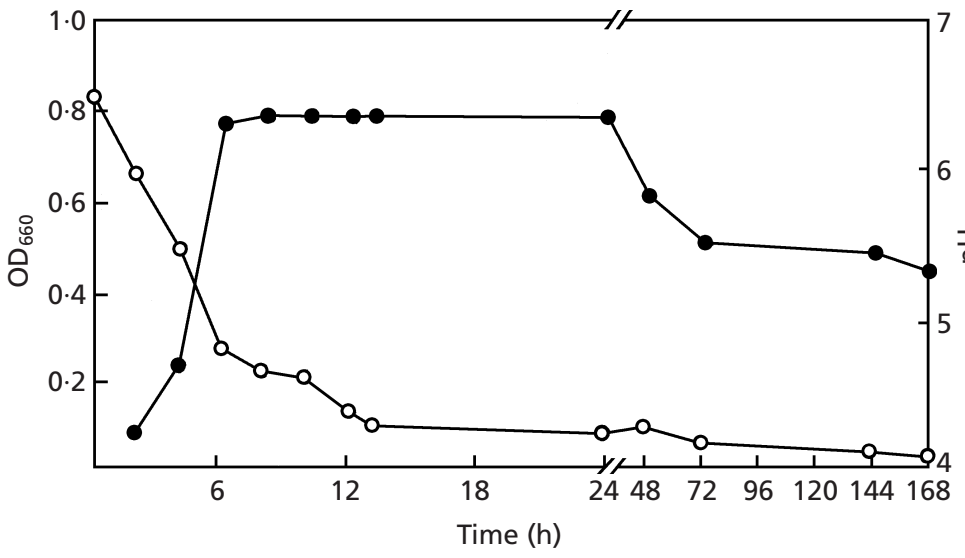

(c)

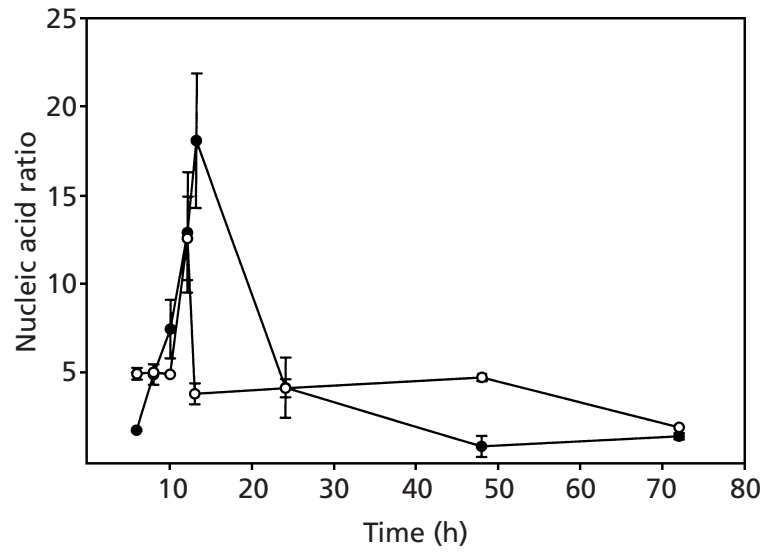

(b)

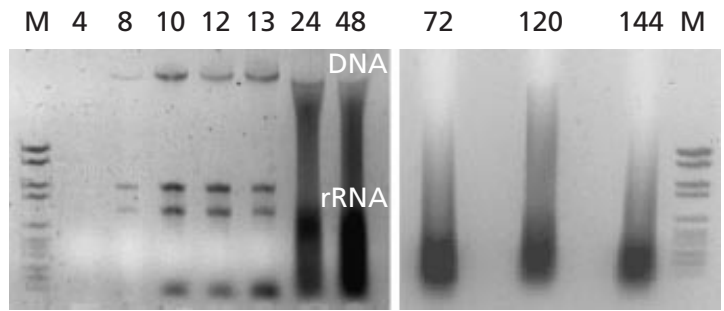

Fig. 3. Growth of $L$. monocytogenes in complex unbuffered medium. (a) $\bullet, \mathrm{OD}_{660} ; \bigcirc, \mathrm{pH}$. Data are means of triplicates and standard deviations were always within $10 \%$ of the mean. (b) Agarose gel electrophoresis of nucleic acid extracts of cells harvested at intervals: 4, 8, 10, 12, 13, 24, 48, 72, 120 and $144 \mathrm{~h}$ incubation. M, Molecular mass marker VI (Roche Diagnostics). (c) Nucleic acid ratios determined by fluorometry $(\bullet)$ and oligonucleotide hybridization $(\bigcirc)$.

contain a heterogeneous population of cells growing at different rates. Therefore, the RNA-DNA ratios reported here are a mean of the population status at a given time. Also, it is noteworthy that nucleic acid ratios do not discriminate between lag phase and starved cells. At these stages of the growth cycle, nucleic acid concentrations (in particular RNA) were at the limits of detection for both methods of analysis applied (Figs 1 and 2).

\section{Growth of $L$. monocytogenes in pH-controlled batch culture}

To determine the effects of prolonged culture of $L$. monocytogenes on survival and nucleic acid content, a $\mathrm{pH}$-controlled batch culture was inoculated and growth was monitored. Growth of the culture showed a predictable exponential phase of about $10 \mathrm{~h}$ duration (Fig. 4a) followed by a prolonged death phase. Viable counts were $10^{10}$ c.f.u. $\mathrm{ml}^{-1}$ after $10 \mathrm{~h}$ and $10^{9}$ c.f.u. $\mathrm{ml}^{-1}$ at the end of the experiment $(456 \mathrm{~h})$. The promotion of L. monocytogenes survival by maintaining the $\mathrm{pH}$ close to neutrality would appear to be correlated with the role of buffered dairy products as a vector for this human pathogen. During exponential growth, intact RNA and DNA were recovered (Fig. 4b) in accordance with the data from batch culture in the absence of $\mathrm{pH}$ control (Fig. 3b). The rapid degradation of DNA in prolonged shake flask culture (Fig. 3b) was not apparent under $\mathrm{pH}$ control where intact DNA was maintained for the $96 \mathrm{~h}$ duration of the experiment (Fig. 4b), while 16S rRNA and $23 \mathrm{~S}$ rRNA were lost. Estimation of RNA-DNA ratios by fluorometry and oligonucleotide probing gave similar patterns (Fig. 5). Nucleic acid ratios increased rapidly to a maximum value observed towards the end of the exponential growth phase and decreased rapidly thereafter. Nucleic acid ratios obtained from samples taken between 96 and $456 \mathrm{~h}$ were generally $<3$, although viable counts were $>10^{9}$ c.f.u. $\mathrm{ml}^{-1}$. Nucleic acid ratios estimated from the starvation phase by fluorometry were consistently greater than those determined by oligonucleotide probing. This could be due to partial nucleic acid degradation and loss of oligonucleotide probe targets in samples taken from the starvation phase.

A number of studies have investigated the effects of prolonged culture or starvation on nucleic acid content and survival in various bacterial species. Maximum RNA-DNA ratio has been observed at, or close to the end of, exponential growth in E. coli (Davis et al., 1986) and resin acid-degrading bacteria (Muttray \& Mohn, 1998), although marine Proteobacteria showed strainspecific responses (Kerkhof \& Kemp, 1999). When E. coli was starved and inoculated into fresh medium, a rapid increase in RNA-DNA ratio at the onset of 
(a)

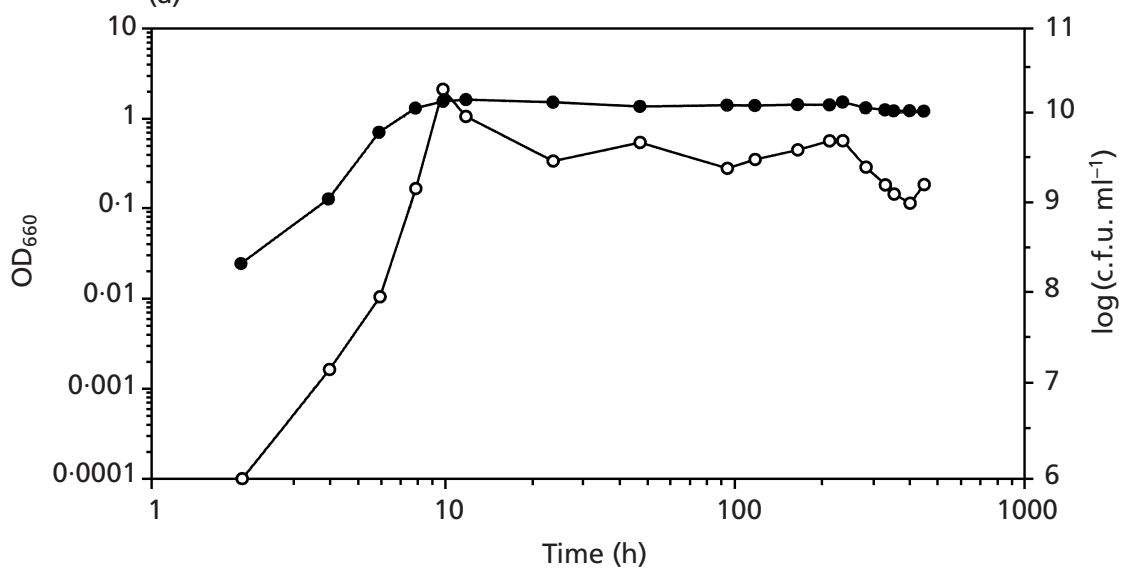

(b)

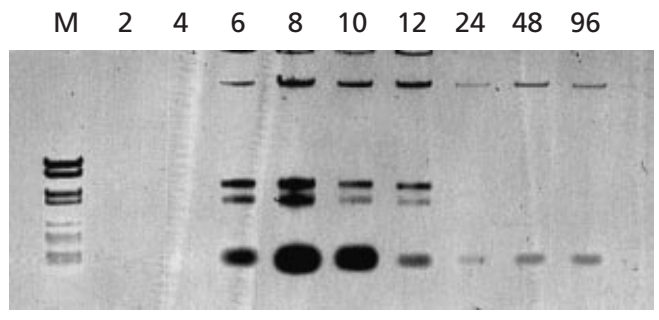

Fig. 4. Growth of $L$. monocytogenes in $\mathrm{pH}-$ controlled batch culture. (a),$O_{660} ; O_{\text {, }}$ c.f.u. $\mathrm{ml}^{-1}$. Data are means of triplicates and standard deviations were always within $10 \%$ of the mean. (b) Agarose gel electrophoresis of nucleic acid extracts of cells harvested at intervals: 2, 4, 6, 8, 10, 12, 24, 48, $96 \mathrm{~h}$ incubation. M, Molecular mass marker VI (Roche Diagnostics).

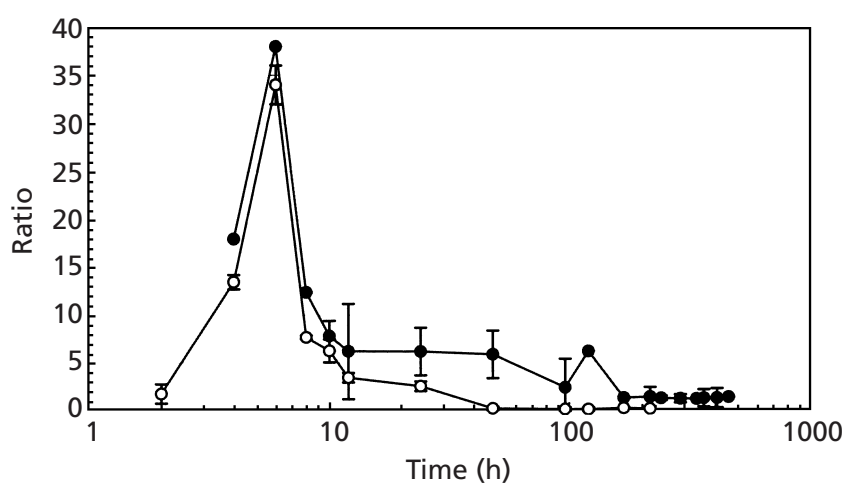

Fig. 5. Nucleic acid ratios in relation to growth of $L$. monocytogenes in $\mathrm{pH}$-controlled batch culture. O, Ratio determined by fluorometry; $\bigcirc$, ratio determined by quantitative oligonucleotide hybridization. Data are means of triplicate determinations; error bars are standard deviations.

exponential growth was not observed (Cangelosi \& Brabant, 1997). During exponential growth, bacteria will tend towards $\mu_{\max }$ and, in theory, contain maximum cellular concentrations of both rRNA and ribosomes. We have calculated from the data in Fig. 5 that the number of ribosomes per cell at the end of exponential growth was 24000 and 26000, as determined by oligonucleotide probing and fluorometry, respectively. The data show that whilst a relatively high viable count can be maintained after exponential growth has ceased (20-456 h), the RNA-DNA ratios decrease rapidly (Fig. $5)$. Indeed, measurement by oligonucleotide probing and fluorometry estimated ribosome numbers of between 200 and 900 per cell, respectively, for this period. This is lower than that determined in a starved Vibrio alginolyticus culture $\left(10^{8}\right.$ c.f.u. $\left.\mathrm{ml}^{-1}\right)$ that contained an estimated 8000 ribosomes per cell (Flardh et al., 1992), but in the same magnitude as that estimated in a marine strain of Pseudomonas stutzeri (Kerkhof \& Ward, 1993).

The rate and degree of ribosomal loss at the onset of bacterial starvation appears to vary, depending upon the species studied and the nature of the starvation imposed. For example, E. coli cells have been reported to lose functional ribosomes rapidly after the onset of starvation (Davis et al., 1986). However in Vibrio alginolyticus, RNA concentration decreased by up to $99 \%$ of exponential levels, but gradually over a $15 \mathrm{~d}$ starvation period (Kramer \& Singleton, 1992). Starvation responses can be remarkably specific, as Kramer \& Singleton (1992) also reported that Vibrio furnissii lost most of its rRNA during only $3 \mathrm{~d}$ of starvation. Maintenance of an active ribosomal pool would appear to be essential for cell survival and recovery. Starvation of E. coli cells resulted in rapid loss and degradation of functional ribosomes that led to rapid loss of viability (Kaplan \& Apirion, 1975a, b; Davis et al., 1986), but a pool in excess of translational requirements was maintained in marine Vibrio spp. (Flardh et al., 1992). Ribosomes may represent a valuable source of metabolites to starved cells, but a critical number must be retained to maintain cell viability (Davis et al., 1986). Differential retention of ribosomes shown by different bacterial species may also affect recovery rates from a stressed environment (Kramer \& Singleton, 1992). It is possible that ribosome 
dimers (100S ribosomes) reported to be of increased resistance to protease and nuclease degradation in $E$. coli (Wada et al., 1990) formed during the prolonged stationary phase, although these were not found in starved Vibrio spp. cells (Flardh et al., 1992).

In this paper, we have demonstrated that L. monocytogenes behaves in a similar manner to E. coli, i.e. viability and rRNA are lost rapidly once exponential growth has ceased. Viability can be maintained under buffered or $\mathrm{pH}$-controlled conditions, enabling persistence of about $10 \%$ of the maximum exponential population, supported by the recovery of intact DNA, but not RNA.

In conclusion, the data presented here for L. monocytogenes show that it is possible to assess RNA-DNA ratios by fluorometry and oligonucleotide probing. In particular, we have shown that L. monocytogenes populations exhibit maximal RNA content late in the exponential growth phase and maintain viability over an extended period in $\mathrm{pH}$-controlled batch culture, with greatly reduced cellular ribosome content when exponential growth has ceased. Having defined the $L$. monocytogenes RNA-DNA characteristics in relation to the growth cycle and maintenance of culture viability, modification of molecular detection methods for this pathogen to also provide information on their physiological status can be addressed.

\section{ACKNOWLEDGEMENTS}

M. G. Milner was supported by a CASE postgraduate studentship provided by BBSRC in association with Unilever Research, Colworth House, Bedford, UK.

\section{REFERENCES}

Amann, R. I., Binder, B. J., Olson, R. J., Chisholm, S. W., Devereux, R. \& Stahl, D. A. (1990a). Combination of $16 \mathrm{~S}$ rRNA-targeted oligonucleotide probes with flow cytometry for analysing mixed microbial populations. Appl Environ Microbiol 56, 1919-1925.

Amann, R. I., Krumholz, L. \& Stahl, D. A. (1990b). Fluorescent oligonucleotide probing of whole cells for determinative, phylogenetic and environmental studies in microbiology. J Bacteriol 172, 762-770.

Bessesen, M. T., Luo, Q., Rotbart, H. A., Blaser, M. \& Ellison, R. T. (1990). Detection of Listeria monocytogenes by using the polymerase chain reaction. Appl Environ Microbiol 56, 2930-2932.

Blais, B. W., Turner, G., Sooknanan, R. \& Malek, L. T. (1997). A nucleic acid sequence-based amplification system for detection of Listeria monocytogenes hlyA sequences. Appl Environ Microbiol 63, 310-313.

Blumberg, D. B. (1987). Creating a ribonuclease free environment. Methods Enzymol 15, 20-24.

Bremer, H. \& Dennis, P. P. (1987). Modulation of chemical composition and other parameters of the cell by growth rate. In Escherichia coli and Salmonella typhimurium: Cellular and Molecular Biology, pp. 1527-1542. Edited by F. C. Neidhardt, J. L. Ingraham, K. B. Low, B. Magasanik, M. Shaechter \& H. E. Umbarger. Washington, DC: American Society for Microbiology.

Cangelosi, G. A. \& Brabant, W. H. (1997). Depletion of pre-16S rRNA in starved Escherichia coli cells. J Bacteriol 179, 4457-4463.
Cano, R. J., Norton, D. M., Inzunza, A. E., Sanchez, J. G. \& Oste, C. (1995). Polymerase chain reaction assay coupled with fluorescence detection on microwell plates for Listeria monocytogenes in foods. J Food Prot 58, 614-620.

Collins, M. D., Wallbanks, S., Lane, D. J., Shah, J., Nietupski, R., Smida, J., Dorsch, M. \& Stackebrandt, E. (1991). Phylogenetic analysis of the genus Listeria based on reverse transcriptase sequencing of $16 \mathrm{~S}$ ribosomal-RNA. Int J Syst Bacteriol 41, 240-246.

Cooray, K. J., Nishibori, T., Xiong, H., Matsuyama, T., Fujita, M. \& Mitsuyama, M. (1994). Detection of multiple virulence-associated genes of Listeria monocytogenes by PCR in artificially contaminated milk samples. Appl Environ Microbiol 60, 3023-3026.

Davis, B. D., Luger, S. M. \& Tai, P. C. (1986). Role of ribosome degradation in the death of starved Escherichia coli cells. J Bacteriol 166, 439-445.

Dell'Anno, A., Fabiano, M., Duineveld, G. C. A., Kok, A. \& Danovaro, R. (1998). Nucleic acid (DNA, RNA) quantification and RNA/DNA ratio determination in marine sediments: comparison of spectrophotometric, fluorometric, and high performance liquid chromatography methods and estimation of detrital DNA. Appl Environ Microbiol 64, 3238-3245.

Edwards, U., Rogall, T., Blocker, H., Emde, M. \& Bottger, E. C. (1989). Isolation and direct complete nucleotide sequence of entire genes. Characterisation of a gene coding for $16 \mathrm{~S}$ ribosomal RNA. Nucleic Acids Res 17, 7843-7853.

Farber, J. M. \& Peterkin, P. I. (1991). Listeria monocytogenes, a food-borne pathogen. Microbiol Rev 55, 476-511.

Ferron, P. \& Michard, J. (1993). Distribution of Listeria spp. in confectioners' pastries from western France: comparison of enrichment methods. Int J Food Microbiol 18, 289-303.

Flardh, K., Cohen, P. S. \& Kjelleberg, S. (1992). Ribosomes exist in large excess over the apparent demand for protein synthesis during carbon starvation in marine Vibrio sp. strain CCUG 15956. J Bacteriol 174, 6780-6788.

Gausing, K. (1977). Regulation of ribosome production in Escherichia coli: synthesis and stability of ribosomal RNA at different growth rates. J Mol Biol 115, 335-354.

George, S. M. \& Lund, B. M. (1992). The effect of culture medium and aeration on growth of Listeria monocytogenes at $\mathrm{pH} 4 \cdot 5$. Lett Appl Microbiol 15, 49-52.

Gilbert, R. J., Miller, K. L. \& Roberts, D. (1989). Listeria monocytogenes and chilled foods. Lancet i, 383-384.

Hiorns, W. D., Hastings, R. C., Head, I. M., McCarthy, A. J., Saunders, J. R., Pickup, R. W. \& Hall, G. H. (1995). Amplification of $16 \mathrm{~S}$ ribosomal RNA genes of autotrophic ammonia oxidizing bacteria demonstrates the ubiquity of nitrosospiras in the environment. Microbiology 141, 2793-2800.

Hof, H. \& Rocourt, J. (1992). Is any strain of Listeria monocytogenes detected in food a health risk? Int J Food Microbiol 16, 173-181.

Kaplan, R. \& Apirion, D. (1975a). The fate of ribosomes in Escherichia coli cells starved of a carbon source. J Biol Chem 250, 1854-1863.

Kaplan, R. \& Apirion, D. (1975b). Decay of ribosomal ribonucleic acid in Escherichia coli cells starved for various nutrients. J Biol Chem 250, 3174-3178.

Kerkhof, L. \& Kemp, P. (1999). Small ribosomal RNA content in marine Proteobacteria during non-steady-state growth. FEMS Microbiol Ecol 30, 253-260.

Kerkhof, L. \& Ward, B. B. (1993). Comparison of nucleic acid hybridization and fluorometry for measurement of the relation- 
ship between RNA/DNA ratio and growth rate in a marine bacterium. Appl Environ Microbiol 59, 1303-1309.

Kjellgaard, N. O. \& Kurland, C. G. (1963). The distribution of soluble and ribosomal RNA as a function of growth rate. $J \mathrm{Mol}$ Biol 6, 341-348.

Klein, P. G. \& Juneja, V. K. (1997). Sensitive detection of viable Listeria monocytogenes by reverse transcription-PCR. Appl Environ Microbiol 53, 4441-4448.

Kramer, J. G. \& Singleton, F. L. (1992). Variations in rRNA content of marine Vibrio spp. during starvation-survival and recovery. Appl Environ Microbiol 58, 201-207.

LePecq, J. \& Paoletti, C. (1966). A new fluorometric method for RNA and DNA determination. Anal Biochem 17, 100-107.

McLauchlin, J. \& Pini, P. N. (1989). The rapid demonstration and presumptive identification of Listeria monocytogenes in food using monoclonal antibodies in a direct immunofluoresence test (DIFT). Lett Appl Microbiol 8, 25-27.

Makino, S.-I., Okada, Y. \& Maruyama, T. (1995). A new method for direct detection of Listeria monocytogenes from foods by PCR. Appl Environ Microbiol 61, 3745-3747.

Michel, C. A. \& Cossart, P. (1992). Physical map of the Listeria monocytogenes chromosome. J Bacteriol 174, 7098-7103.

Muttray, A. F. \& Mohn, W. W. (1998). RNA/DNA ratio as an indicator of metabolic activity in resin acid-degrading bacteria. Water Sci Technol 37, 89-93.

Neidhardt, F. C., Ingraham, J. L. \& Schaechter, M. (1990). Physiology of the Bacterial Cell: a Molecular Approach. Sunderland, MA: Sinauer Associates.

Nørrung, B. \& Skovgaard, N. (1993). Application of multilocus enzyme electrophoresis in studies of the epidemiology of Listeria monocytogenes in Denmark. Appl Environ Microbiol 59, 2817-2822.

Pine, L., Malcolm, G. B., Brooks, J. B. \& Danshevar, M. I. (1989). Physiological studies on the growth and utilization of sugars by Listeria species. Can J Microbiol 35, 245-254.

Powell, H. A., Gooding, C. M., Garett, S. D., Lund, B. M. \& McKee, R. A. (1994). Proteinase inhibition of the detection of Listeria monocytogenes in milk using the polymerase chain reaction. Lett Appl Microbiol 18, 59-61.

Rosset, R., Julien, J. \& Monier, R. (1966). Ribonucleic acid composition of bacteria as a function of growth rate. J Mol Biol 18, 308-320.

Scheu, P., Gasch, A. \& Berghof, K. (1999). Rapid detection of Listeria monocytogenes by PCR-ELISA. Lett Appl Microbiol 29, 416-420.

Smith, J. L. \& Buchanan, R. L. (1990). Identification of supplements that enhance the recovery of Listeria monocytogenes on modified Vogel-Johnson agar. J Food Saf 10, 155-163.

Sokal, R. R. \& Rohlf, F. J. (1995). Biometry: The Principles and Practice of Statistics in Biological Research, 3rd edn. New York: Freeman.

ter-Steeg, P. F. \& Pieterman, F. H (1991). Effects of aeration conditions, temperature and $\mathrm{pH}$ on growth rate and maintenanceenergy demands of Listeria innocua (the physiological substitute of L. monocytogenes) in a (semi-) chemically defined medium. Confidential Laboratory Progress Report. Vlaardingen, The Netherlands: Unilever Research.

Verheul, A., Hagting, A., Amezaga, M.-R., Booth, I. R., Rombouts, F. M. \& Abee, T. (1995). A di- and tripeptide transport system can supply Listeria monocytogenes Scott A with amino acids essential for growth. Appl Environ Microbiol 61, 225-233.

Wada, A., Yamazaki, Y., Fujita, N. \& Ishihama, A. (1990). Structure and probable genetic location of a ribosome modulation factor associated with $100 \mathrm{~S}$ ribosome ribosomes in stationary phase Escherichia coli cells. Proc Natl Acad Sci U S A 87, 2657-2661.

Wang, R. F., Cao, W.-W. \& Johnson, M. G. (1992). $16 \mathrm{~S}$ rRNAbased probes and polymerase chain reaction method to detect Listeria monocytogenes cells added to foods. Appl Environ Microbiol 58, 2827-2831.

Young, K. M. \& Fogeding, P. M. (1993). Acetic, lactic and citric acids and $\mathrm{pH}$ inhibition of Listeria monocytogenes Scott $\mathrm{A}$ and the effect on intracellular pH. J Appl Bacteriol 74, 515-520.

Received 4 December 2000; revised 14 May 2001; accepted 31 May 2001. 